\title{
Elektronik Kütüphanecilik Semineri: Bir Değerlendirme
}

\author{
An Evaluation of a Seminar on Electronic Librarianship
}

\section{Yaşar Tonta* ve Mehmet Emin Küçük*}

\section{Öz}

Hacettepe Üniversitesi Edebiyat Fakültesi Kütüphanecilik Bölümü tarafından 4-8 Eylül 2000 tarihlerinde Beytepe'de (Ankara) "Elektronik Kütüphanecilik" konulu bir seminer düzenlenmiştir. Bu seminere çeşitli üniversite, kamu, özel ve askeri kuruluş kütüphanelerinden ve bilgi merkezlerinden toplam 29 kişi katılmıştır. Seminerde elektronik kütüphanecilikle ilgili çeşitli konularda her birisi 50 dakika süren 17 oturum ve 11 uygulama gerçekleştirilmiştir. Seminere katılanlara hem her oturumla ilgili hem de genel olarak seminerin tamamıyla ilgili anketler uygulanmıştır. Katılımcıların büyük bir çoğunıuğu (\%81) semineri "çok iyi" bulmuşlardır. Bu makalede, adanmış bir takımın uyumı ve özverili çalışmaları sonucu gerçekleştirilen söz konusu seminerde edinilen deneyimler özetlenmekte ve katıımcılara uygulanan anket sonuçları değerlendirilmektedir.

Anahtar Sözcükler: Elektronik Kütüphanecilik

\section{Abstract}

The seminar on "Electronic Librarianship", organized by the Department of Library Science of Hacettepe University, took place in Ankara from 4-8 September 2000. Some 29 librarians representing university, public, private and military libraries participated in this seminar. A total of 17 lectures, each lasting 50 minutes, on various aspects of electronic librarianship were delivered. Eleven practical sessions provided participants much needed "hands-on" experience on electronic information sources and services. Participants filled out a questionnaire after each session. An overwhelming majority (81\%) of participants found the seminar "very good". This paper summarizes the experiences of a committed seminar team and evaluates the questionnaire results.

Keywonds: Electronic Librarianship

\footnotetext{
† H.Ü. Edebiyat Fakültesi Kütüphanecilik Bölümü öğretim üyesi, \{tonta, mkucuk\}@hacettepe.edu.tr
} 


\section{Giriş̧}

Hacettepe Üniversitesi (H.Ü.) Edebiyat Fakültesi Kütüphanecilik Bölümünde oluşturulan çalışma gruplarından birisi de "Seminer-Sempozyum" Çalışma Grubudur. Bu Grup, kütüphanecilikle ilgili çeşitli konularda seminerler düzenlenmesinin yararlı olacağı sonucuna varmıştır. Bölüm Kurulunun da bu öneriyi desteklemesiyle birlikte Mayıs 2000'de çalışmalar başlatılmıştır. Bölüm öğretim üyelerinden Yaşar Tonta ve M. Emin Küçük'ün önerdikleri "Elektronik Kütüphanecilik" konulu seminerin gerçekleştirilmesine karar verilmiş ve adı geçen öğretim üyelerinin önderliğinde bir takım çalışması başlatılmıştır. Yapılan işbölümü sonucu Dr. Tonta seminer koordinatörü ve eğitmen, Dr. Küçük seminer yürütücüsü ve eğitmen, Bölüm araştırma görevlilerinden Erol Olcay grafik tasarım ve laboratuvar sorumlusu, Bölüm uzmanlarından Faik Demirbaş web sorumlusu, araştırma görevlileri Umut Al, Tuğkan Tepiltepe, Yurdagül Ünal ve Selim Vanlı ise seminer hazırlık ve uygulamalarında yardımcı elemanlar olarak görevlendirilmişlerdir.

Mayıs 2000'de çalışmalara başlayan seminer takımı önce seminerin duyurulması ve seminerin gerçekleştirilmesiyle ilgili lojistik desteğin sağlanması üzerinde yoğunlaşmış, daha sonra ise seminer sunuş ve uygulamalarının içeriği üzerinde çalışmıştır.

Seminerin duyurulması ve tanitımı, posta, elektronik posta (e-posta), kütüphanecilerin tartışma listesi "kutup-|" ve seminer web sitesi (http:/www.kut.hacettepe.edu.tr/seminer/) aracılığıyla, destek ve katılımcı sağlamak üzere sektörde çalışan yerli ve yabancı firmalar ve bilgi merkezleri olmak üzere iki gruba yönelik olarak gerçekleştirildi. Farklı sektörlerde yer alan kütüphane ve dokümantasyon daire başkanlıklarına da birer mektup gönderilerek seminerin duyurusu ve tanıtımı yapılmıştır. Potansiyel olarak seminere destek verebilecek firmalarla iletişime geçilerek, kendilerine seminer süresince ürünlerini tanıtmak amacıyla stand açabilecekleri, seminer sosyal etkinliklerini (yemek, kokteyl ve çanta dağıtımı gibi) destekleyebilecekleri, ürünlerinin kullanımına yönelik deneme hesapları açabilecekleri bildirilmiştir. Yapılan çağrıya firmaların çoğunluğu olumlu yanıt vererek ürünlerine yönelik deneme hesapları açmış- 
lar, düzenlenen yemek ve kokteyllere ve katılımcılara dağıtılan çanta ve içeriğine maddi destek sağlamışıardır. Ayrıca, EBSCO Information Services Türkiye ve TOTAL Bilişim şirketleri, ürün ve hizmetlerini tanıtmak amacıyla birer stand açmışlardır.

Seminerin yaygın olarak tanıtımının yanı sıra seminerin başarısını etkileyecek bir diğer unsur hiç kuşkusuz böyle bir seminerin gerekli kıldığı lojistik desteğin sağlanmasıdır. Uygulamalarła desteklenen bir seminer sırasında elektrik ve Internet bağlantısının kesilmesi ve katılımcıların rahat etmesini sağlayacak olanakların sağlanamaması seminerin başarısını olumsuz yönde etkileyebilirdi. Seminer öncesinde Ankara'da yapılan sürekli elektrik kesintileri ve Hacettepe Üniversitesinin Internet bağlantısındaki düzensizlik seminer takımını endişelendiren en önemli konu olmuştur. Internet bağlantısının gerçekleştirilememe olasılığı göz önünde bulundurularak laboratuvardaki tüm bilgisayarların modem-telefon bağlantısı kurularak yedek bir olanağın yaratı|ması düşünülmüştür. Ancak, yaklaşık 40 bilgisayara telefon bağlantısının sağlanması mümkün olamadı. Kaldı ki elektrik kesilmesi durumunda bu çözümler çalışır hale getirilemeyecekti. Bunun yerine Üniversitenin Bilgi İşlem Dairesi Başkanlığındaki teknik ekibin seminer süresince "alarm"da olması ve elektrik kesintisi olması durumunda Üniversitenin kesintisiz güç kaynağının seminerin gerçekleştirileceği yer olan Edebiyat Fakültesi Bilgisayar Laboratuvarını destekleyebilmesi için gerekli alt yapının sağlanması en uygun çözüm olarak ortaya çıktı. Bu çözüm seminer süresince hiç bir aksaklık meydana gelmeden işledi.

Internet bağlantısının kesilmesi durumunda sunuşların ve uygulamaların aksamadan sürdürülebilmesi için tüm uygulamaların önceden gerçekleştírilerek videoya kaydedilmesi seçeneği de değerlendirildi. Ancak bu tür "konserve" uygulamaların katılımcıları "canlı" Internet bağlantısının kazandıracağı deneyimlerden yoksun bırakacağı düşünülerek bu yola gidilmedi. Çünkü o zaman uygulama oturumları da eğitmenlerin diğer oturumlarda yaptıkları sunuşlara benzeyecek ve katılımcılar elektronik bilgi kaynaklarını ve bilgi hizmetlerini deneme şansı elde edemeyeceklerdi. 
Teknik desteğin yanı sıra katılımcıların konaklama, haberleşme, sosyal etkinliklere ulaşım, kahvaltı, öğle yemeği, ders aralarındaki ikramlar vb. gibi gereksinimlerini kolayca giderebilmeleri için gerekli lojistik destek sağlanmış ve ders sunumlarına ilişkin dosyalar önceden hazırlanarak katılımcılara kayıt sırasında dağıtıımıştır.

Elektronik Kütüphanecilik Seminerinin içeriği tarafımızdan hazırlanmıştır. Önce elektronik kütüphanecilikle ilgili konular belirlenerek oturum başlıkları saptanmış, bu oturumlarla ilgili ne tür uygulamalar yapılacağı kararlaştırılmışıır. Programda önce elektronik kütüphanecilikle ilgili genel oturumlar, daha sonra elektronik bilgi kaynakları ve bilgi hizmetleriyle ilgili temel konular (derme yönetimi, işbirliği, elektronik bilgi kaynaklarının kataloglanması, vd.), son olarak da elektronik kütüphanelerin kurulmasına ve yönetimine ilişkin oturumlara yer verilmesinin yararlı olacağı sonucuna varılmıştır.

Belirlenen oturumlarla ilgili sunuşların hazırlanması toplam iki aylık bir süre almıştır. Bu süre içerisinde oturum konularıyla ilgili çeşitli kaynaklar değerlendirilmiş, sunuşlarda örnek olarak kullanılabilecek elektronik bilgi kaynakları ve bilgi hizmetlerinin web saytaları belirlenmiştir. Daha sonra sunuş slaytları PowerPoint ortamında hazırlanarak bastırılmış ve katılımcılar için hazırlanan dosyalara konulmuştur. Söz konusu slaytlar, seminere katılamayanların da sunuş slaytlarından yararlanması jçin, seminerin başlamasından yaklaşık bir hafta önce, yukarıda verilen seminer web saytasından herkesin kulIanımına açılmıştır.

\section{Seminer Programı}

Seminer 4 Eylül Pazartesi günü H.Ü. Kütüphanecilik Bölümü öğretim üyesi Prof. Dr. Nilüfer Tuncer ve H.Ü. Edebiyat Fakültesi Dekanı Prof. Dr. Tuğrul Inal'ın açılış konuşmalarıyla başlamıştır. Seminer süresince her birisi 50 dakikalık toplam 17 sunuş, yedi uygulama oturumu ve iki firma sunuşu gerçekleştirilmiştir. Seminer programı Ek 1 'de sunulmuştur. Daha önce de değinildiği gibi, seminerle ilgili ayrıntılı bilgilere, seminer programına ve sunuşlar sı- 
rasında kullanılan slaytların kopyalarına yukarıda verilen seminer web sayfasından da erişilebilmektedir.

Seminerin ilk gününde (4 Eylül 2000) "Internet ve Kütüphanecilik", "Elektronik Yayıncılık" ve "Elektronik Bilgi Kaynakları (I-II)" başlıklı sunuşlar yapılmıştır. "Internet ve Kütüphanecilik" dersi kapsamında Internet ve araçları, Internet üzerindeki bilgi kaynaklanı tanıtılmış, Internet'te içerik ile, bilgi teknolojisi ve içerik bütünleşmesi sorunları tartışılarak elektronik kütüphane kavramı açıklanmıştır. "Elektronik Yayıncılık" oturumunda, "elektronik yayın"ın tanımı yapılmış, elektronik yayıncılığın tarihsel gelişimi ve elektronik yayıncılığa ilişkin sorunlar incelenmiştir. "Elektronik Bilgi Kaynakları (I-II)" oturumunda ise, elektronik bilgi kaynakları türleri, elektronik kütüphane, arşiv, müze, haber ajansları, web tv ve radyolar, bibliyografik ve tam metin veri tabanları, kooperatif ve konsorsiyum çalışmaları örneklenerek incelenmiştir. Bu oturumlara yönelik uygulamalarda ise ăg aracılığıyla erişilebilen çeşitli bilgi kaynakları (çevrimiçi kataloglar, e-dergiler, e-kitaplar, e-gazeteler, e-tezler, e-kütüphaneler, vd.), bibliyografik ve tam metin veri tabanları tanıtıımıştır. Seminer süresince Cambridge Scientific Abstracts, EBSCO Information Services, SwetsBlackwell, TDNet gibi birçok yayınevi ve firmaya ait veri tabanlarına, elektronik dergilerin tam metinlerine ve çeşitli bilgi hizmetlerine (içindekiler sayfası hizmetleri, güncel duyuru hizmetleri, vd.) deneme amacıyla erişim sağlanmıştır. (Seminer süresince katılımcılara açık olan elektronik veri tabanları ve diğer bilgi hizmetlerinin listesi Ek 2'de verilmektedir.) EBSCO Information Services Türkiye, SwetsBlackwell, Gale Grubu ve ITS firmalarının temsilcileri seminer sırasında katılımcılarin sorularını yanıtlamışlardır. ProQuest, Web of Science, Encyclopaedia Britannica gibi bazı veri tabanlarına ve bilgi hizmetlerine ise H.Ü. Merkez Kütüphanesi aracılığıyla erişim sağlanmıştır.

Seminerin ikinci gününde (5 Eylül 2000) "Arama Motorları: Biłgi Keşfetme ve Erişim Araçları", "Elektronik Bilgi Hizmetleri", "Elektronik Derme Yönetimi" ve "Elektronik Bilgi Kaynaklarının Sağlanmasında ve Kullanımında İşbirliği ve Konsorsiyumlar" başlıklı oturumlar yapılmıştır. "Arama Motorları: Bilgi Keşfetme ve Erişim Araçları" oturumu kapsamında, bilgi keşfetme ve erişim araçła 
rı tanıtılmış ve çalışma ilkeleri incelenmiştir. "Elektronik Bilgi Hizmetleri" oturumu kapsamında, kullanıcı hizmetlerindeki yönelimler, bunların yönetim ve örgütsel yapıya yansımaları, erişim/sunum seçenekleri, elektronik bilgi hizmeti türleri, hizmetlerin kişiselleştirilmesi ve kullanıcı-personel eğitimi konuları aktarılmıştır. "Elektronik Derme Yönetimi" oturumu kapsamında, "erişimsahip olma" ikilemi tartışılmış, derme yönetim stratejileri, elektronik derme yönetimini etkileyen faktörler, derme yönetim modelleri ve elektronik kaynak seçim ölçütleri incelenmiştir. "Elektronik Bilgi Kaynaklarının Sağlanmasında ve Kullanımında İ̧̧birliği ve Konsorsiyumlar" oturumu kapsamında ise işbirliği kavramı ve işbirliğini zorunlu kılan nedenler tanımlanmış, mevcut konsorsiyumlardan bazı örnekler verilmiş, konsorsiyum kurma aşamaları ve ülkemizdeki konsorsiyum çalışmaları ve lisans anlaşmaları tartışı|mıştır.

Uygulamalarda ise çeşitli arama motorları tanıtılmış, çeşitli firmalar tarafından sunulan danışma, içindekiler sayfası, güncel duyuru ve elektronik belge sağlama hizmetleri ile bazı elektronik kütüphaneler tarafından sunulan kìşiselleştirilmiş hizmetler (örneğin, Kuzey Karolina Eyalet Üniversitesince geliştirilen "My Library") tanıtılmıştır. Bir başka uygulama oturumunda ise elektronik içerik sağlamak amacıyla imzalanan lisans anlaşmalarının belli başlı bölümleri gözden geçirilmiş ve dikkat edilmesi gereken nokłalar üzerinde durulmuştur.

Seminerin üçüncü gününde (6 Eylül 2000) "Elektronik Kütüphaneciliğin Ekonomisi", "Elektronik Kütüphanecilik ve Entellektüel Mülkiyet Hakları", "Elektronik Kütüphanelerde Koruma ve Arşivleme" ve "Elektronik Yayınların Kataloglanması ve Dizinlenmesi” başlıklı sunuşlar yapı|mıştır. "Elektronik Kütüphaneciliğin Ekonomisi" oturumu kapsamında elektronik bilgileri fiyatlandırma modelleri incelenmiş, ekonomik sorunlar ve ekonomik modeller tartışılarak lisans ücretlerine ilişkin örnekler verilmiştir. "Elektronik Kütüphanecilik ve Entellektüel Mülkiyet Hakları" oturumu kapsamında, dijital yayın teknolojisi, değişen telif hakkı anlayışı, telif hakkı kapsamı ve telif hakkı yasaları ve ihlallere karşı teknolojik önlemler tartışılimıştır. "Elektronik Kütüphanelerde Koruma ve Arşivleme" oturumu kapsamında koruma ve arşivleme kavramları tanımlanmış, erişim-kopyalama-arşivleme ilişkisi ortaya konulmuş, yönetimsel 
sorunlar ve konuyla ilgili görevler tartışılarak mevcut projelerden bazıları örneklenmiştir. "Elektronik Yayınların Kataloglanması ve Dizinlenmesi" oturumu kapsamında ise, kataloglama ve dizinleme kavramları tanımlanmış, çevrimiçi dünyadaki bilginin düzenlenmesine ilişkin sorunlar ortaya konulmuş, çözüm olarak ortaya çıkan "metadata" kavramı, metadata oluşturma araçla$\mathrm{r}$, metadata standartları ve Dublin Core metadata standardı incelenmiş ve dijital nesne tanımlama (DOI-Digital Object Identifier) sistemi hakkında bilgi verilmiştir.

Belirtilen derslerin yanı sıra EBSCO Information Services Türkiye firması temsilcileri ürünlerini tanıtan bir sunuş yapmışlardır. Uygulama oturumlarında ise bazı dizinleme servisleri tanıtımış, çeşitli metadata editör ve yaratıcılarından örnekler incelenerek bazı elektronik kaynaklarının metadata bilgisi oluşturu|muş/yaratılmıştır.

Seminerin dördüncü gününde (7 Eylül 2000) "Elektronik Kütüphanecilik Alt Yapısı", "Elektronik Kütüphanelerde Erişim Yönetimi", "Elektronik Kütüphaneler ve Otomasyon Yazılımları" ve "Elektronik Kütüphanelerin Kurulması ve Yönetimi" oturumları gerçekleştirilmiştir.

"Elektronik Kütüphanecilik Alt Yapısı" oturumu kapsamında, alt yapı ve alt yapının temel bileşenleri, yeni teknolojiler ve teknolojik sorunlar, teknik standartlar, bazı örnek mimariler incelenerek, ülkemizde konuyla iligili olarak nelerin yapılabileceği tartışılmıştır. "Elektronik Kütüphanelerde Erişirn Yönetimi" oturumunda erişim yönetimi kavramı açıklanarak erişim yönetimi sorunları tartışılmış, erişim yönetimine ilişkin yaklaşımlar işlenerek, konu, İngiltere'deki ATHENS Ulusal Erişim Yönetim Sistemi örneklenerek inçelenmiştir. "Elektronik Kütüphaneler ve Otomasyon Yazılımları" oturumu kapsamında elektronik kütüphane ve bileşenleri ve sistem seçiminde göz önüne alınacak unsurlar incelenerek, katılımcıların kütüphanelerinde varolan yazılımlar tartışmaya açılmıştır. "Elektronik Kütüphanelerin Kurulması ve Yönetimi" oturumunda ise sistem kurma aşamaları, seçenekler ve yaklaşımlar incelenmiştir.

Uygulama oturumlarında yurt dışındaki dağıtık mimariye dayalı olarak geliştirilen bazı elektronik kütüphanelerin web sayfaları ziyaret edilmiştir. TO- 
TAL Bilişim Teknolojileri şirketi tarafindan geliştirilen TEKS (TOTAL Elektronik Kütüphane Sistemi) adlı kütüphane otomasyon yazıłımı firma temsilcisi tarafından tanıtılmıştır.

Seminerin beşinci ve son gününde ( 8 Eylül 2000) ise "Elektronik Bilgi Yönetimi" başlıklı genel bir oturum gerçekleştirilmiştir. Bu ders kapsamında, elektronik bilgi çevresi, elektronik bilgi stratejisi ve politikaları, elektronik bilginin denetimi, bilgi davranışı ve kültürü, elektronik bilgi personeli, elektronik bilgi yönetimi süreçleri, elektronik bilgi mimarisi, elektronik bilgi teknolojisi ve elektronik bilgi yönetimindeki yaklaşımlar incelenmiştir. Dersin ardından tartışma açılmış, bazı firma temsilcilerinin de katıldığı bir oturumda seminerin genel bir değerlendirmesi yapılmış ve elektronik kütüphanecilik alanındaki bazı yönelimlere dikkat çekilmiştir. Seminer değerlendirme sonuçlarını özetleyen kısa bir sunuşun ardından katılanlara katılımcı belgelerinin verilmesiyle seminer sona ermiştir.

\section{Değerlendirme}

Katılımcılar seminer sonunda, seminerin tamamının değerlendirilmesine yönelik bir "Genel Değerlendirme Formu" (Ek 3) doldurmuşlardır. Ayrıca, seminerde yapılan her sunuştan sonra katılımcılardan sunuşla ilgili sorular içeren bir "Değerlendirme Formu" (Ek 4) doldurmaları istenmiştir. Seminer sonunda bu formlarda yer alan bilgiler bir istatistik değerlendirme yazılımına (SPSS for Windows) aktarılmış ve seminerle ilgili katılımcıların görüş ve önerileri değerIendirilmiştir. Aşağıdaki değerlendirmeler söz konusu formlardan edinilen bilgilere dayanmaktadır.

\section{Genel Değerlendirme}

Seminere katılanların \%81'i seminerin tamamını genelde "Çok iyi", \%19'u ise "İyi" olarak değerlendirmişlerdir (Şekil 1). (Diğer seçenekler işaretlenmemiştir.) 


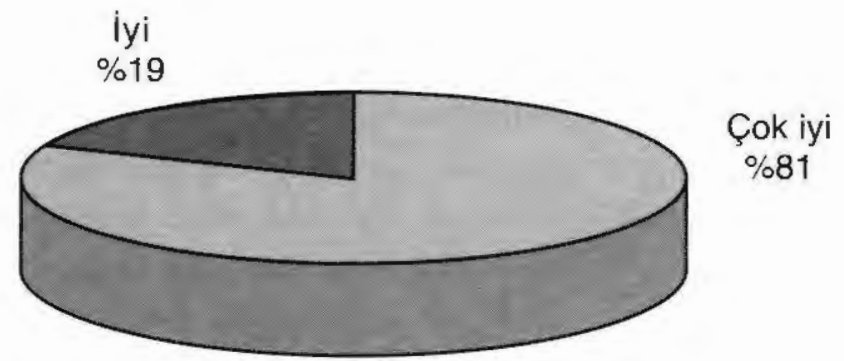

Şekil 1. Sunuşların Genel Değerlendirmesi $(N=26)$

Seminer sırasında sunulan laboratuvar olanakları katılımcılar tarafından son derece yeterli bulunmuştur (\%85 "Çok iyi”, \%15 “íy”). Katılımcıların $\% 46$ 'sı laboratuvar uygulamalarını "Çok iyi", \%38'i "lyi", \%4'ü ise "Zayıf" olarak nitelendirmişlerdir (\%12'si ise bu soruyu yanıtlamamışlardır). Sunuşların yapıldığı sınıfı katılımcıların \%46'sı "Çok iyi", \%42'si "liyi", \%8'i "Zayıf" bulmuşlardır.

Katılımcılar seminer sırasında personelin ilgisinden (\%85 "Çok iyi", \%15 "Iyi") son derece memnun kalmışlardır. Katılımcıların seminer sırasındaki yönlendirme (\%77 "Çok iyi", \%19 "lyi") ve konaklama/ulaşım hizmetleriyle (\%69 "Çok iyi", \%19 "Iyi") ilgili düşünceleri de olumludur. Katılımcıların yaklaşık \%75'i sunuşlar sırasındaki ikramlanı ve firmalar tarafından verilen kokteyl ve akşam yemeklerini "Çok iyi" olarak nitelendirmişlerdir.

Katılımcıların \%69'u seminer öncesi iletişim hizmetlerini "Çok iyi”, \%27'si ise "lyi" olarak nitelendirmişlerdir. Aynı oranlar seminer öncesi web hizmetleri için sırasıyla $\% 69$ ve $\% 23$, seminer öncesi konaklama ve rezervasyon bilgileri için ise \%54 ve \%12'dir (katılımcıların \%35'i bu soruyu yanıtlamamışlardır-bu oran konaklama konusunda seminer takımından bir talepte bulunmayanları yansıtmaktadır). 
Sunuşların Değerlendirilmesi

Katılımcıların \%64'ü sunuşları "Çok iyi", \%34'ü ise "lyi" olarak değerlendirmişlerdir. (Katılımcıların \%2'sinin bu soruyu yanıtlamadıkları saptanmıştır. "Geliştirilmesi gerekli" ve "Zayıf" seçenekleri hiçbir katılımcı tarafından işaretlenmemiştir. Toplam 414 form doldurulmuştur.)

Katılımcıların her bir sunuşla ilgili değerlendirmeleri Şekil 2'de verilmiştir. Bütün sunuşlar katıımcılar tarafından genellikle "Çok iyi" olarak değerlendirilmiştir. Toplam 17 sunuşun her birini "Çok iyi" olarak değerlendirenlerin oranı $\% 50$ ile $\% 82$, "Iyi" olarak değerlendirenlerin oranı ise $\% 14$ ile $\% 50$ arasında değişmektedir (sunuş başlıkları numaralarıyla birlikte Ek 1'de verilmiştir)

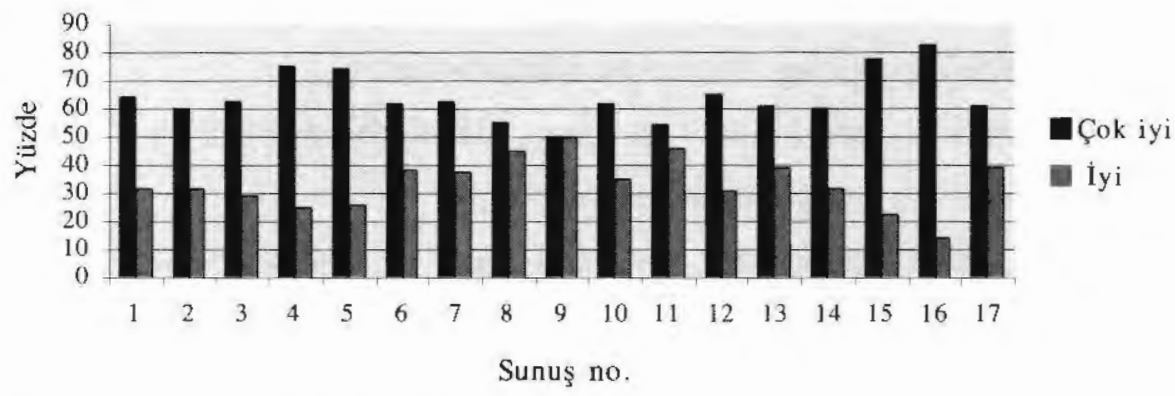

Şekil 2. Sunuşların Değerlendirilmesi

Formda yer alan içerik ve sunuş hakkındaki diğer sorularla ilgili değeriendirmeler aşağıda verilmiştir.

Katılımcıların tamamı eğitmenlerin bilgi düzeyini "Çok iyi" ya da "iyi" olarak nitelendirmişlerdir. Katılımcılar eğitmenlerin sunuş stillerini ve materyali anlaşılır biçimde sunmalarını \%99 oranında "Çok iyi" ya da "iyi" bulmuşlar, eğitmenlerin sorulara verdikleri yanıtlardan da \%98 oranında memnun kalmışlardır.

Katılımcıların \%98'i sunuş içeriklerinin uygun düzeyde sunulduğunu, \%97'si sunuş içeriklerinin yararlı materyali kapsadığını ve iyi düzenlendiğini, 
$\% 96$ 'sı içeriğin ilgi ve ihtiyaçlarına uygun olduğunu ve yararlı slayt ve notlar içerdiğini, \%94'ü sunuşların etkili aktiviteler içerdiğini düşünmektedirler.

Katılimcların Sunuşlarla ilgili Görüş ve Önerileri

Katılımcılar her sunuşla ilgili bazı görüş ve önerilere de değerlendirme formlarında yer vermişlerdir. Bu görüş ve önerilerden bazıları aşağıdadır:

"Türkçe terimlerde biraz problem yaşadim." (1. sunuş: Internet ve Kütüphanecilik)

"Teknik terimlerin Türkçe ve ingilizce karşliklan her zaman bir arada verilmeli, çünkü bu konuda sıkınthyız. Anlamın bilmediğim bazl kelimelerin Türkçe karşıliklarım bu seminerde gördüm ve son derece yararlı oldu." (1. sunuş: Internet ve Kütüphanecilik)

"Mükemmel." (1. sunuş: Internet ve Kütüphanecilik)

"Yeterli örnekler göremedim." (2. sunuş: Elektronik Yayıncılık)

"Mükemmel." (2. sunuş: Elektronik Yayıncılık)

"Zaman darlığı [nedeniyle]... biraz hızh geçti." (3. sunuş: Elektronik Bilgi Kaynakları 1)

"Biraz daha geniş zaman ayrlabilirdi." (4. sunuş: Elektronik Bilgi KaynaklaII II)

"Mükemmel." (4. sunuş: Elektronik Bilgi Kaynakları II)

"Faydall olacağın düşündügünüz birkaç web sitesine (ortak uygulama olarak) giriş yapmamızı sağlar mısını??" (4. sunuş: Elektronik Bilgi Kaynakları Ii)

"Son derece akıcı ve anlaşılir bir anlatım." (5. sunuş: Arama motorları)

"Arama stratejillerine daha fazla değinilebilirdi." (5. sunuş: Arama motorları)

"Zaman az geldi. Bu bölüme daha çok zaman gerekli idi." (6. sunuş: Elektronik Bilgi Hizmetleri)

"Sadece üniversite kütüphaneleri ile ilgiliydi." (8. sunuş: Elektronik Bilgi Kaynaklarının Sağlanmasında ve Kullanımında Işbirliği)

"Konsorsiyumla ilgili olarak branş kütüphanelerinin durumu da araştırımall. 
Bu konuda üniversite kütüphaneleri dişında kalan kütüphaneler ne yapabilir? " (8. sunuş: Elektronik Bilgi Kaynaklarının Sağlanmasında ve Kullanımında İşbirliği)

"Şirket arşivlerinde de kaytlarmn elektronik olarak tutulmasına ilişkin bölüm de eklenirse daha iyi olurdu." (11. sunuş: Elektronik Kütüphanelerde Koruma ve Arşivleme)

"Uluslararası projelerden örnekler daha iyi incelenebilirdi. Türkiye örnekleri? ".(11. sunuş: Elektronik Kütüphaneterde Koruma ve Arşivleme)

"Bu oturumda ortak bir uygulama yapilmalyydı." (12. sunuş: Elektronik Yayınların Kataloglanması ve Dizinlenmesi)

"Konu çok iyi ama yeterli açiklama yapılmadı. Ayrıntılara inilebilirdi. Çok hızlı geçildi." (12. sunuş: Elektronik Yayınların Kataloglanması ve Dizinlenmesi)

"Harika bir ders ve çok iyi bir organizasyon." (14. sunuş: Elektronik Kütüphanelerde Erişim Yönetimi)

"Alt ayr yazllm ana hatlan ile veren tablo, yine isim kullanimadan (firma) gerçek rakamlarla verilebilir miydi?" (16. sunuş: Elektronik Kütüphanelerin Kurulması ve Yönetimi)

"Bence 16. oturuma daha geniş yer ayrlabilir ve daha detayl anlatılabilirdi (örnekler de verilirơl)." (16. sunuş: Elektronik Kütüphanelerin Kurulmaș ve Yönetimi)

"Sanyorum seminerin en can alıcr oturumu oldu ve ögrendiğimiz temel bitgilerle birlikte bu oturum bir bütün oluşturdu." (17. sunuş: Elektronik Bilgi Yönetimi)

Birçok katılımcı doldurdukları formlarda seminerle ilgili geneł görüş ve önerilerini belirtmişler ve başka seminer konuları da önermişlerdir. Bunlardan bazıları herhangi bir sıra gözetilmeksizin aşağıda verilmiştir:

"Yurt dışında ve yurt içinde gördügüm en iyi organizasyonlardan biriydi. Çok teşekkürler." 
"Seminer son derece iyi organize edilmiş. Hem içerik olarak hem diḡer aktivitelerin düzenlenmesi olarak bizim açımızdan oldukça yeterliydi."

"Seminerde program çok yoğun olduğu için bazı konulara derinlemesine inilecek zaman kalmadı ve çok hızlı geçildiği için fazla not alma imkânımı da olmadi. Klasördeki sunuş ekranlar yanına kısaca birer cümle ile bunlara ait açıklamalar yazilabilir miydi diye düşünüyorum."

"Bilişim teknolojileri doğrultusunda mesleki bilimin gelişimi konusunda bu für seminerlerin sürekli ve düzenli olarak yapılmasın dilerim. Teşekkürler."

"Seminer kapsaminda yer alan bazı konular kapsamlı oldugu halde tam olarak açıklanamadı. Bu da sanırım öngörülen sürenin aşılması kaygısındandi. Ileriki zamanlarda kapsam dahilinde birkaç konu detayl olarak incelenebilir (kataloglama, kütüphane yönetimi, organizasyon...gibi). Teşekkürler."

"Seminer çok profesyonel(ce) düzenlenmişti. Emeg̈i geçen tüm Bölüm çaIIşanlarna teşekkür ediyorum."

"Yılda en az bir defa Elektronik Kütüphanecilik alanındaki gelişmeler gözden geçirilebilir."

"Özel kütüphane-Araştrrma kütüphanesi kütüphanecileri için daha özel bir seminer program düzenlenebilir."

"Laboratuvarda ortak uygulama örnekleri hazırlanirsa daha jyi olur."

"Her ayrntı düşünülerek hazılanmış çok başarıl ve faydalı bir seminer oldu."

"Zaman zaman bazı konular çok hızlı geçildi. Bu tür seminerleri sıkça tekrarlamal."

"Jçerik olarak yoğun bir seminer için bir hafta biraz kısa gibi görünüyor. Belki konulan biraz sınırlayıp içerigini biraz daha zamana yayarak açıklama ve tartışma ortamın artırmak uygun olabilir."

"Seminer konuları biraz daha smirlandıriabilir; çok yoğun olması dikkat dağınıkı̆̆ı̆ yaratıyor."

"Uygulamalar daha spesifik konular üzerinde yaplip (kursiyerler) uygulayıcılar sonuçları paylaşıp tartışabilir' yöntemi de değerlendirilebilir." 
"Elektronik bilgi hizmeti, derme yönetimi ve bilgi yönetimi konuları kendi başlarına ve daha kısa süreli (2-3 gün) başiı başına seminer konuları olabilir."

"Temel sorun bilgi kullanma alışkanliğı olmamasından kaynaklanıyorsa -ki bu doğrudur- bu noktada 'topluma bilgi kullanımı nasıl ögretilir' ya da 'bilgi kullanma kültürü nası kazandirlir?' sorunlan çerçevesinde konular daha derin işlenebilir. 'Bilgi Yönetimi' konulu bir seminer etrafında bunlan tartışabiliriz. Aynı konuda küçük ölçekli kütüphaneler için zenginleştirilmiş örnekler içeren bir seminer düzenlenebilir. Ya da düzenlediğiniz seminerdeki örnekler daha genele göre yeniden gözden geçirilebilir."

"Güzel organize edilmiş ve planlanmıştı."

"Böyle bir seminere ev sahipligi yapan H.Ü. Ed. Fak. Kütüphanecilik Bölümüne çok teşekkürler. Bu ve benzeri seminerlerin devamı dileğiyle."

"Kütüphane yazilmman konusunda ülkemizdeki resmi ve ticari üreticilerin tümünün katılacağı 2 günlük bir seminer düzenlenmesi. ligi alanımıza giren firmaların büyük çoğunluğunun katılımlarının (sunumlan ve sergileri ile) să̆lanması."

"Kataloglama ve dizinleme ile ilgili daha detaylı bilgi verilebilir."

"Elektronik bilgi kaynaklarnin uygulamalan daha uzun olabilirdi. Genel olarak herşey çok ince düşünülmüş. Ilgi çok iyiydi."

"Konu çok genel olduğu için bazı sunumlar çok hizlı geçildi. Bazl elektronik kaynakları (önemli olanlanı) daha detayls görmek isterdim. Benim kullandğım, kullanacağım kaynaklan sonra daha ayrıntılı görmek isterdim."

Katılımclara hangi konularda seminer düzenlenmesini bekledikleri de sorulmuş, katılımcıların önerdikleri seminer konuları aşağıda sunulmuştur (önerinin yanındaki rakam öneren kişi sayısını göstermektedir):

- Avrupa Birliği yolunda Türk kütüphaneleri ve kütüphaneciliği

- Bilgi hizmetlerinin pazarlanması

- Bilgi merkezleri

- Derme yönetimi

- Elektronik bilgi yönetimi (özel kütüphanelerde) (5) 
- Elektronik biligi hizmetleri

- Elektronik kütüphanecilik

- Elektronik bilgi kaynaklarının sağlanması ve kullanımı

- Elektronik ortamlarda kurumsal bilgi kaynakları

- Elektronik bilgi kaynaklarının sağlanmasında ve yönetiminde hukuksal sorunlar ve çözüm önerileri

- Elektronik bilgi kaynaklarının tanıtımı

- Konsorsiyal olarak elektronik dergilerin sağlanması; konsorsiyum çalışmalarının gerekliliği

- Kütüphane hizmetlerinde yeni teknolojik gelişmeler ve Türkiye'deki araştırma kütüphanelerinde uygulama olanakları

- Kütüphane otomasyonunda standardizasyon

- Kütüphanelerarası işbirtiği

- Kütüphanelerde kullanılan otomasyon yazılımları (avantaj ve dezavantaj vb.) (2)

- Kütüphanelerin değişen teknolojiyle bağlantılı olarak verdikleri özel hizmetler

- Maliyet analizi

- Metadata oluşturulması

- Web'e dayalı kütüphane sayfalarının planlanması

- Yönetim bilgi sistemleri ve kütüphaneler

- Yönetimsel ekonomi

- Teknik eğitim

Ulusal düzeyde yapılmış bir seminerde ve farklı kütüphane türlerinden gelen katılımcılar tarafından dile getirilen bu öneriler, benzer seminerler düzenleyecek kurumların göz önüne alabileceği öneriler olup, uygulamadaki meslektaşlarımızın eğitim/seminer konusundaki beklentilerinin belirlenmesinde bir "alış veriş" listesi özelliği göstermektedir.

\section{Sonuç}

Katılımcıların semineri gerek içerik gerekse sunuş açısından başarılı buldukları ortaya çıkmaktadır. Bazı sunuşlar süre bakımından yetersiz kalmıştır. Önerilerden de anlaşılacağı üzere elektronik bilgi yönetimi, elektronik bilgile- 
rin sağlanması ve düzenlenmesi, kütüphane otomasyonu vb. gibi çeşitli konularda benzer seminerlere intiyaç duyulmaktadır. Bazı katılımcılar bu tür seminerlerin düzenli olarak yinelenmesini önermektedirler. Bazı katılımcılar uygulamaların da sunuş biçiminde (scripted) gerçekleştirilmesini yeğlemektedir. Lojistik açıdan sunuşların yapıldığı sınıfın yeterli olmadığı ortaya çıkmıştır. Bu tür seminerlerin laboratuvar ortamında, her katılımcının önünde Internet bağlantısı olan bir bilgisayar ile gerçekleştirilmesi katılımcıların daha etkin bir biçimde öğrenmelerine yardımcı olacaktır kanısındayız.

Kuşkusuz bu seminer hem katılımcılar hem de semineri düzenleyenler açısından öğretici olmuştur. Öncelikle, bu tür bir organizasyon adanmış ve uyum içinde çalışabilecek bir ekibi, uygun niteliklere sahip personelin görevlendirilmesini ve seminer ekibini eşgüdüm içinde yönlendirebilecek seminer liderini gerektirmektedir.

Diğer taraftan, ders içeriklerinin katılımcıların beklentilerine uygun hale getirilmesi son derece titiz bir çalışmayı, benzer özellikleri göstermeyen (homojen olmayan) grubun ders esnasında çok iyl algılanmasını ve dersin bu gözleme göre şekillendirilmesini zorunlu kılmaktadır. Derslerin yanı sıra seminerin bazı sosyal etkinliklerle zenginleştirilmesi, seminer süresince motivasyonu bozacak (elektrik kesintisi, bilgisayar arızaları, yiyecek-içecek servislerindeki aksamalar) unsurların ortadan kaldırılması ve ders notlarının katılımcılara önceden sunulması bir seminerin başarısınł etkileyen önemli faktörlerdendir.

Sonuç olarak; sürekli eğitim etkinliklerine kütüphanecilikte de büyük gereksinim duyulmaktadır. Bu ve benzeri sürekli eğitim seminerlerinin mesleki dernekler ve kütüphanecilik bölümleri tarafından sürdürülmesi gerektiği açıktır. Önerilen konular çerçevesinde farklı gruplara yönelik başka seminerler düzenlendiği takdirde katılımcıların bu seminerlere ilgi gösterecekleri ortaya çıkmaktadır. Bu ilginin iyi düzenlenmiş çeşitli sürekli eğitim etkinlikleriyle tatmin edilmesi bir zorunluluk haline gelmiştir. 


\section{Ek 1. Seminer Programı}

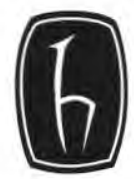

Hacettepe Üniversitesi Edebiyat Fakültesi Kütüphanecilik Bölümü

'ELEKTRONIK KÜTÜPHANECILIK' Semineri

4 - 8 Eylül 2000, Beytepe, Ankara

Program

\section{Eylül 2000 Pazartesi}

\begin{tabular}{|c|c|}
\hline $09: 30-10: 00$ & Kayit \\
\hline $10: 00 \cdot 10: 15$ & Açilış \\
\hline $10.15-11: 05$ & 1.Internet ve Kütüphanecilik \\
\hline $11: 05 \cdot 11: 20$ & Ara \\
\hline $11: 20-12: 10$ & 2. Elektronik Yayıncılık \\
\hline $12: 10-13: 20$ & $\begin{array}{l}\text { Öğle Yemeği (Beytepe Öğretim Üyeleri Kafeteryası) Gale Grubu ve ITS'nin } \\
\text { katkılarıyla }\end{array}$ \\
\hline $13: 20-14: 10$ & 3. Elektronik Bilgi Kaynakları I \\
\hline $14: 10-14: 55$ & $\begin{array}{l}\text { Uygulama I: Çevrimiçi kataloglar, e-dergiler, e-kitaplar, e-gazeteler, e-tezler, } \\
\text { e-kütüphaneler, vd. }\end{array}$ \\
\hline $14: 55-15: 10$ & Ara \\
\hline $15: 10-16: 00$ & 4. Elektronik Bilgi Kaynakları II \\
\hline $16: 10-16: 55$ & Uygulama II: Bibliyografik ve tam metin veri tabaniar \\
\hline
\end{tabular}

\section{Eylül 2000 Salı}

\begin{tabular}{|c|c|}
\hline $09: \overline{30-10: 20}$ & 5. Arama Motorları: Bilgi Keşfetme ve Erişim Araçları \\
\hline $10: 20-11: 05$ & Uygulama III: Alta Vista, Yahoo!, Lycos, Dogpile, Arabul, Netbul, vd. \\
\hline $10.05-11: 20$ & Ara \\
\hline $11: 20-12: 10$ & 6. Elektronik Bilgi Hizmetleri \\
\hline $12: 10-13: 20$ & Yemek arası \\
\hline $13: 20 \cdot 14: 10$ & 7. Elektronik Derme Yönetimi \\
\hline $14: 10-14: 55$ & $\begin{array}{l}\text { Uygulama IV: Danışma, güncel duyuru, elektronik belge sağlama ve içinde- } \\
\text { kiler sayfası hizmetleri }\end{array}$ \\
\hline $14: 55-15: 10$ & Ara \\
\hline $15: 10-16: 00$ & $\begin{array}{l}\text { 8. Elektronik Bilgi Kaynaklarının Sağlanmasında ve Kullanımında } \\
\text { Işbirliği ve Konsorsiyumlar }\end{array}$ \\
\hline $16: 10-16: 55$ & Uygulama V: Konsorsiyumlar ve Lisans Anlaşmaları \\
\hline $19: 30-21: 30$ & Kokteyl (Sheraton Oteli, Kavaklıdere) Ebsco Türkiye'nin katkılarıyla \\
\hline
\end{tabular}




\section{Eylül 2000 Çarşamba}

\begin{tabular}{|l|l|}
\hline $09: 30-10: 20$ & 9. Elektronik Kütüphaneciliğin Ekonomisi \\
\hline 10:20 $-11: 05$ & Firma Sunumu (Nilüfer Saros - Erol Gökduman, Ebsco Türkiye) \\
\hline $10.05-11: 20$ & Ara \\
\hline $11: 20-12: 10$ & 10. Elektronik Kütüphanecilik ve Entellektüel Mülkiyet Hakları \\
\hline $12: 10-13: 20$ & Yemek arası \\
\hline $13: 20-14: 10$ & 11. Elektronik Kütüphanelerde Koruma ve Arşivleme \\
\hline $14: 10-14: 55$ & Uygulama VI: Elektronik Arşivleme Projeleri \\
\hline $14: 55-15: 10$ & Ara \\
\hline $15: 10-16: 00$ & 12. Elektronik Yayınların Kataloglanması ve Dizinlenmesi \\
\hline 16:10-16:55 & Uygulama VII: Metadata Editör ve Yaratıcılanı \\
\hline
\end{tabular}

\section{Eylül 2000 Perşembe}

\begin{tabular}{|c|c|}
\hline $09: 30-10: 20$ & 13. Elektronik Kütüphanecilik Alt Yapısı \\
\hline $10: 20-11: 05$ & Uygulama VIII: Internet, intranet uygulamalar \\
\hline $10.05-11: 20$ & Ara \\
\hline $11: 20-12: 10$ & 14. Elektronik Kütüphanelerde Erişim Yönetimi \\
\hline $12: 10-13: 20$ & Yemek arası \\
\hline $13: 20-14: 10$ & 15. Elektronik Kütüphaneler ve Otomasyon Yazılımları \\
\hline $14: 10 \cdot 14: 55$ & Firma Sunumu (Semra Polat, Total Bilişim Teknolojileri) \\
\hline $14: 55-15: 10$ & Ara \\
\hline $15: 10 \cdot 16: 00$ & 16. Elektronik Kütüphanelerin Kurulması ve Yönetimi \\
\hline $16: 10-16: 55$ & Uygulama IX: Örnek olay \\
\hline $19 ; 30-22: 00$ & $\begin{array}{l}\text { Kokteyl ve Akşam Yemeği (Yer: Beyaz Ev, Beytepe) Swets \& Blackwell'in } \\
\text { katkılarıyla } \\
\text { Not: Şehirden servis 19:00'da Sıhhiye Köprüsü üzerinden kalkacak ve } \\
\text { Bahçelievler Son Durak'a da uğrayacaktır. }\end{array}$ \\
\hline
\end{tabular}

\section{Eylül 2000 Cuma}

\begin{tabular}{|l|l|}
\hline $09: 30-10: 20$ & $\mathbf{1 7}$. Elektronik Bilgi Yönetimi \\
\hline $10: 20-11: 05$ & Tartışma \\
\hline $10.05-11: 20$ & Ara \\
\hline $11: 20-12: 10$ & Değerlendirme \\
\hline $12: 10-12: 40$ & Öneriler ve Kapanış \\
\hline
\end{tabular}




\section{Ek 2. Elektronik Kütüphanecilik Semineri Süresince Erişilebilen Elektronik Kaynaklar}

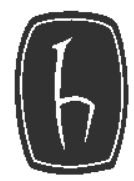

Hacettepe Üniversitesi Edebiyat Fakültesi Kütüphanecilik Bölümü

"Elektronik Kütüphanecilik" Semineri

4-8 Eylül 2000, Beytepe, Ankara

\section{Internet'ten Erişilen Elektronik Bilgi Kaynakları}

Amazon.com Internet kitap̧̧ısı

Ariadne Kütüphaneciliğe ilişkin elektronik đergi.

Booklist Kitap eleştirisi.

Çeşitli kütüphanelerin çevrimiçi katalogları (Bilkent Üniversitesi, Milli Kütüphane vd.)

DIALOG 500'e yakın bibliyografik/tam metin veri tabanı (şifre gerekli)

Encyclopaedia Britannica

Encyclopedia.com

IDEAL: International Digital Electronic Access Library (Academic Press, W.B. Saunders, Churchill Livingstone, Bailliere Tindall dergilerini içermektedir. ) (şifre gerekli)

JSTOR: Journal Storage Online (200 civarında sosyal ve insani bilimler dergisinin ilk sayılarından itibaren tam metinlerinin yer aldığı bir elektronik derme. ) (şifre gerekli)

MEDLINE PubMed ve Internet Grateful Med

Oxford English Dictionary

Türkiye Standart Kataloğu

\section{Hacettepe Üniversitesi Kütüphanesi Aracılığıyla Erişilen Elektronik Veri Tabanları}

ULAKBiM aracılığıyla erişilen veri tabanları (Web of Science vd.) http:/atlas.ulakbim.gov.tr:8590/

ERIC (ERIC veri tabanı, eğitim konusuyla ilgili makele, doküman ve yayınları kolaylıkla tarama olanağı sunmaktadır. Veri tabanı, Resources in Education (AIE) dokümanları ve 750'den çok eğitimle ilgili dergiyi içeren Current Index to Journals in Education (CIJE) makaleleri ve 850'nin üzerinde ERIC Digest dokümanlarının tam meținlerini içerir.) 
GALENet (Expanded Academic Index, Business File ve diğer veri tabantarı)

Expanded Academic ASAP (International Ed.) (Gale) 1980 - (Sanattan sosyal ve beşeri bilimlere, bilim ve teknolojiye kadar bütün disiplinlerde araștırma gereksinimini karşılayan akademik düzeyde dergiler ve gazeteleri içeren bir veri tabanıdır.)

Gale Group General Business File International (Gale) 1980 - (Endüstri, ticaret, yönetim, ekonomi ve politika konularındaki son gelişmelere ilişkin broker araştı ma raporları, ticarỉ yayınlar, gazeteler, dergiler ve rehberlerin tam metinlerine erişim mümkündür.)

MathSciNet (American Mathematical Sociely tarafından hazırlanan matematikle ilgili derleme ve makaleler içeren bir verì tabanı.)

MEDLINE NLM-Internet Grateful Med (MEDLINE ABD ve 70 farklı ülkede basılan 4000 'den fazla tıp ve sağlık bilimıerine ilişkin süreli yayınları indeksleyerek bibliyografik kayıt ve özlerini verir. 1966'dan günümüze 10 milyonun üzerinde bibliyografik kayıt içermektedir.)

ProQuest (Eğitim, insan bilimleri, sosyal bitimler, güzel sanatlar ve tıp alanlarındaki dergilere tam metin erişim olanağı sunmaktadır.)

Science@Direct (Elsevier Science dergilerine tarama ve tam metin erişimi sağlayan bir veri tabanłdır. Ayrıca güncel duyuru hizmeti de verilmektedir.)

Web of Science (ISI) (Web of Science (WoS), ISI tarafından yayımlanan SCI ve SSCI'nin Internet erişim arayüzüdür. Bu veri tabanı yalnızca ilk yazardan değil, diğer yazarłardan da åıf taraması yapma olanağı sunmaktadır.)

\section{Bibliyografik ve Tam Metin Elektronik Veri Tabanları, Elektronik Dergiler}

\section{Cambridge Scientific Abstracts}

\section{INFOTRAC}

EBSCO Information Services (Çeşitli alanlardan bibliyografik ve tam metin bilgilerin yer aidığı bir servis.)

Emerald Library Çeşitli alanlardan tam metin dergilerin yer aldığı bir veritabanı

GaleNet Biography Resource Center + The Complete Marquis Who's Who ----Literature Resource Center - LRC, Scribner, Twayne US, Twayne English, and Twayne World Authors

TDNet (Teldan şirketince sağlanan elektronik dergi koleksiyonu.)

\section{ProQuest}

SIlverPlatter

Swetsnet Navigator 


\title{
Ek 3. Genel Değerlendirme Formu
}

\author{
H.Ü. Kütüphanecilik Bölümü \\ Elektronik Kütüphanecilik Semineri \\ 4-8 Eylül 2000, Beytepe, Ankara
}

\section{Genel Değerlendirme Formu}

Lütfen aşağıdaki hususlarıa ilgili görüşlerinizi belirtiniz.

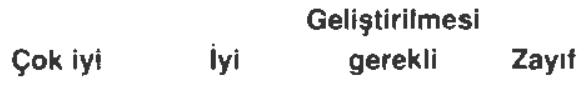

Konferans öncesi

IIletişim

Web hizmetleri

Konakłama Rezervasyon

$\begin{array}{llll}\lrcorner & \lrcorner & \lrcorner & \square \\ \lrcorner & \lrcorner & \lrcorner & \sqsupset \\ \lrcorner & \lrcorner & \lrcorner & \sqsupset\end{array}$

Konferans esnasında

Yönlendirme

Personein ihgisi

Konaklama ve ulaşım

Laboratuvar

Derslik

İkramlar

Resepsiyontar

Uygulamalar

\section{Genel değerlendirme}

Genel memnuniyet (içerik, uygulamalar, vd.)

$\begin{array}{llll}\lrcorner & \lrcorner & \lrcorner & コ \\ \lrcorner & \lrcorner & \lrcorner & \sqsupset \\ \lrcorner & \lrcorner & \lrcorner & \sqsupset \\ \sqcup & \lrcorner & \lrcorner & \square \\ \lrcorner & \lrcorner & \sqsupset & \sqsupset \\ \lrcorner & \lrcorner & \sqsupset & \lrcorner \\ \lrcorner & \lrcorner & \sqsupset & \lrcorner \\ \lrcorner & \lrcorner & \lrcorner & \lrcorner\end{array}$

Önereceğiniz diğer seminer konuları:

Seminere yönelik öneriler:

Formun arkasını da kullanabilirsiniz. 


\section{Ek 4. Değerlendirme Formu}

H.Ü. Kütüphanecilik Bölümü

Elektronik Kütüphanecilik Semineri

4-8 Eylül 2000. Beytepe, Ankara

\section{DEĞERLENDIRME FORMU}

Oturumun adı:

Tarih:

Lülten aşağıdaki hususlarla ilgili görüş̧lerinizi belirtiniz.

İçerik

Iletişim

Yararlı materyali kapsiyor

İlgi ve ihtiyaçłarıma uyģun

ly| düzenlenmiş

Uygun düzeyde sunuldu

Etkili aktiviteler

Yararlı slayt ve notlar

\section{Sunuş}

Eğgiticinin konuyla iigili biigisi

Eğiticinin sunuş stili

Eğitichinin materyali anlaşılır

bir biçimde sunmas।

Eğiticinin sorulara verdiği

cevaplar

Bu oturumu daha da geliş̧tirmek için önerileriniz:

Başka açıklama ve önerileriniz:

Bu oturumun tamamını nasıl değeflendirirsiniz?
Çok iyi

$\square$
\lrcorner
$\sqsupset$
$\sqsupset$
$\square$
$\square$
$\sqsupset$

Çok iyi

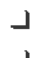

\lrcorner

$\square$

コ
Iyi

Geliştirilmesi

gerekli Zayıf

$コ$
\lrcorner
$\sqsupset$
$\sqsupset$
$\square$
$\sqsupset$
$\beth$

Geliş̧irilmesi

Iyi gerekli Zayıl

コ

コ

コ

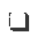

コ

コ

$\begin{array}{cccc}\text { Çok iyi } & \text { Iyi } & \text { Orta } & \text { Zayıf } \\ \sqcup & \sqsupset & \sqcup & \sqsupset\end{array}$

